\title{
IbM PEMANFAATAN LIMBAH TERNAK KELOMPOK TANI KEDUNG SUMBER KAB. BOJONEGORO
}

\author{
Eko Noerhayati ${ }^{1)}$ Unung Lesmanah ${ }^{2)}$ \\ ${ }^{1}$ Jurusan Teknik Sipil Univerditas Islam Malang \\ email: eko unisma@ymail.com \\ 2 Jurusan Teknik Mesin Universitas Islam Malang \\ email: ununglesmanah@gmail.com
}

\begin{abstract}
ABSTRAK
Desa Kedung Sumber merupakan sebuah desa yang terletak di Kabupaten Bojonegoro Jawa Timur. Desa ini terkenal dengan hasil pertanian padi, lombok dan bawang merah. Kondisi tanahnya sedikit berkapur namun cukup subur untuk ditanami padi. Petani disini menggunakan sapi sebagai tenaga bantu dalam mengolah sawah dan sebagian sengaja diternakkan untuk dibudidayakan. Selama ini kotoran ternak di manfaatkan sebagai pupuk organik dengan cara dibiarkan di tempat terbuka namun beratap. Hal ini kurang efektif karena menimbulkan bau tak sedap dan pemanasan global.Tujuan kegiatan adalah untuk mengurangi kondisi pembuangan kotoran ternak sapi yang kurang sehat dan kurang menjaga lingkungan maka perlu dibuat alat yang dapat menangkap gas metan dari kotoran ternak dan memanfaatkannya sebagai energi alternatif berupa panas. Rencana kegiatan adalah membangun instalasi biogas sebagai penangkap gas metan yang dihasilkan kotoran sapi dan memberikan pengetahuan tentang biogas serta pupuk organik ke patani mitra di kab Bojonegoro. Tujuan khusus kegiatan IbM adalah : Meningkatkan kemandirian kelompok tani peternak sapi masyarakat desa Kedung Sumber melalui pengembangan pemanfaatan kotoran sapi menjadi biogas ; meningkatkan pengetahuan dan ketrampilan kelompok peternak sapi dalam mengelola kotoran ternak menjadi pupuk organik. Target khusus yang ingin dicapai : terbangunnya instalasi biogas, terlaksananya pelatihan biogas danpupuk cair, tersedianya kompor biogas, terlaksananya pedampingan pemanfaatan biogas.Metode yang digunakan untuk mencapai tujuan adalah : Menerapkan teknologi tepat guna berupa instalasi biogas sebagai penangkap gas metan kotoran sapi ; melakukan pelatihan dan pendampingan dalam pemanfaatan, pengembangan dan perawatan instalasi biogas; melakukan pelatihan pemanfaatan pupuk cair dari kotoran sapi.
\end{abstract}

Kata kunci : biogas, pupuk organik, petani, bawang merah, Lombok

\section{Latar Belakang}

Desa Kedung Sumber merupakan sebuah desa yang terletak di Kabupaten Bojonegoro Jawa Timur. Desa ini terkenal dengan hasil pertanian padi, lombok dan bawang merah. Kondisi tanahnya sedikit berkapur namun cukup subur untuk ditanami padi. Petani disini menggunakan sapi sebagai tenaga bantu dalam mengolah sawah dan 
sebagian sengaja diternakkan untuk dibudidayakan. Selama ini kotoran ternak di manfaatkan sebagai pupuk organik dengan cara dibiarkan di tempat terbuka namun beratap. Hal ini kurang efektif karena menimbulkan bau tak sedap dan pemanasan global.

Jumlah sapi di desa ini 67 ekor yang tersebar di RT 13 RW 2 Dukuh

Sugihan desa Kedung Sumber. Mitra dalam kegiatan ini adalah:

1. Kelompoktani \& Peternak Sapi Mekar Jaya desa Kedung Sumber Kec Temayang kab. Bojonegoro

2. Kelompoktani \& Peternak Sapi Pacar Asri desa Kedung Sumber Kec Temayang kab Bojonegoro.

Produksi yang dihasilkan adalah : pupuk organik dari limbah sapi dengan kapasitas produksi perhari 1,72 ton / hari (basah) yang dijual ke pemilik tanaman yang membutuhkan pupuk kandang.

\section{Permasalahan Mitra}

Secaraumnumpersoalanmitraadalahsebagaiberikut :

(1) Kotoran sapi menimbulkan bau tak sedap saat dijadikan pupuk organik

(2) Belum mengenal pengelolaan instalasi biogas

(3) Belum bisa membuat pupuk cair

Solusi yang ditawarkan :

(1) Dibangun instalasi biogas

(2) Pelatihan pemanfaatan biogas

(3) Pelatihan pembuatan dan pengemasan pupuk cair

\section{TARGET DAN LUARAN}

Target dan luaran hasil kegiatan secara ringkas adalahs ebagai berikut :

\begin{tabular}{llll} 
No & \multicolumn{1}{c}{ Kegiatan } & \multicolumn{1}{c}{ Target } & \multicolumn{1}{c}{ Luaran } \\
1 & Membangun instalasi biogas & UKM kelompok tani & instalasi biogas \\
2 & Pelatihan pupuk cair & UKM kelompok tani & $\begin{array}{l}\text { Metode (pembuatan } \\
\text { pupuk cair) }\end{array}$
\end{tabular}

\section{METODE PELAKSANAAN}

Metode yang dilaksanakan dalam pelaksanaan pengabdian adalah sebagai berikut :

- Sosialisas ikegiatan kemitra UKM,

- Pembangunan instalasi biogas dan pelatihan biogas

- Pengujian instalasi biogas dilanjutkan dengan pendampingan pemakaian instalasi biogas kemitra

- Pemberian pelatihan perawatan dan pengoperasiannya ke UKM Mitra.

- Pelatihan pembuatan pupuk cair.

- Evaluasi kegiatan yang dilakukan antara tim pengabdi PT bersamaMitra UKM. 
Dalam kegiatan ini mitra peternak diminta partisipasinya dalam bentuk :

1. Memberi bantuan tenaga kerja sebagai pembantu dalam pelaksanaan berbagai kegiatan yang dilangsungkan.

2. Mitramem beribantuan dalam bentuk peralatan kerja atau sejenisnya dalam melengkapi penyempurnaan hasil kegiatan.

3. Menyediakan tempat tinggal untuk tim pengabd ikarena kegiatanakan berlangsung cukup lama dan tempat tinggal pengabdi jauh dari lokasi kegiatan.

\section{HASIL YANG DICAPAI}

1. Mengkoordinasi pelaksanaan kegiatan dengan mitra peternak sapi

2. Menguji dan mendampingi masyarakat dalam menggunakan biogas sebagai sumber energi alternatif

3. Diklat pemanfaatan pupuk cair organic dari sisa biogas.

\section{KESIMPULAN DAN SARAN}

Kesimpulan:

1. Masyarakat sangat membantu dalam pelaksanaan kegiatan dalam bentuk tenaga kerja, tempat tinggal, akomodasi, transportasi dan informasi

2. Desa Kedung Sumber ,Kec. Temayang ,Kab. Bojonegoro merupakan wilayah yang potensial untuk dikembangkan menjadi desa mandiri berdasarkan potensinya berupa air yang berlimpah, dekat area hutan perhutani serta masyarakat yang gemar bekerja keras.

\section{DAFTAR PUSTAKA}

Deublein, D. and Steinhauser, A, 2008. Biogas fromWaste and Renewable Resource, Wiley-VCHVerlag GmbH \& Co. KGaA ,Weinheim.

Hartono, R. danKurniawan, T. 2009. Produksi Biogas dari Jerami Padi dengan Penambahan Kotoran Kerbau, Prosiding Seminar Nasional

Teknik Kimia Indonesia- SNTKI 2009, Bandung ,19-20 Oktober 2009.

Lateng, N. 2010. Pengaruh Jumlah Biostarter dan Waktu Fermentas ipada Pemanfaatan Limbah Kulit Buah Kakao Sebagai Bahan Baku Pembuatan Biogas. Tesis. Program Pascasarjana.UNHAS, Makassar.

Prajayana, F. I., Romli, M danSuprihatin. 2011. Kajian Konversi Limbah Padat Jerami Padi Manjadi Biogas.Tesis.Institut Pertanian Bogor, Bogor.

Wahyuni, Sri. 2008. Biogas.Penebar Swadaya: Depok 